\title{
PENGARUH PENYEMPROTAN BORON DAN GA 3 PADA PERTUMBUHAN, PRODUKSI, DAN MUTU BENIH KEDELAI (Glycine max [L.] Merrill)
}

\author{
Ermawati, Agustiansyah \& Putu Deva Ari Sandhy \\ Jurusan Agroteknologi, Fakultas Pertanian, Universitas Lampung \\ Jl. Prof. Soemantri Brojonegoro, No. 1 Bandar Lampung 35145
}

\begin{abstract}
ABSTRAK
Produksi kedelai di Indonesia masih rendah. Upaya untuk meningkatkan produksi kedelai adalah melalui pemupukan unsur hara mikro boron dan pemberian hormon giberelin $\mathrm{GA}_{3}$. Penelitian ini bertujuan untuk mengetahui pengaruh penyemprotan kombinasi konsentrasi boron dan $\mathrm{GA}_{3}$ pada pertumbuhan, produksi, dan mutu benih kedelai. Penelitian ini dilaksanakan di Laboratorium Lapang Terpadu Fakultas Pertanian Universitas Lampung dari April sampai dengan September 2015. Perlakuan disusun dalam rancangan perlakuan faktor tunggal tidak terstruktur yaitu kombinasi boron dan $\mathrm{GA}_{3}$. Perlakuan terdiri dari kombinasi konsentrasi boron dan $\mathrm{GA}_{3}(0+0) \mathrm{ppm},(5+20) \mathrm{ppm},(5+40) \mathrm{ppm},(5+60) \mathrm{ppm},(5+80) \mathrm{ppm},(5+100) \mathrm{ppm},(10+$ $20) \mathrm{ppm},(10+40) \mathrm{ppm},(10+60) \mathrm{ppm},(10+80) \mathrm{ppm}$, dan $(10+100) \mathrm{ppm}$. Perlakuan diulang sebanyak delapan kali. Perbedaan antarkombinasi perlakuan diketahui dengan menggunakan standar deviasi. Hasil penelitian menunjukkan bahwa pemberian kombinasi konsentrasi boron dan $\mathrm{GA}_{3}(10+60) \mathrm{ppm}$ dapat meningkatkan cenderung tinggi pada persen perkecambahan, kecepatan perkecambahan, potensi tumbuh maksimum, tinggi tanaman, jumlah cabang, jumlah daun, jumlah daun trifoliat, jumlah polong total, jumlah polong isi, dan bobot biji. Pemberian kombinasi konsentrasi boron dan $\mathrm{GA}_{3}$ (5+ 60) ppm dapat meningkatkan cenderung tinggi pada persen perkecambahan, bobot kering kecambah normal, potensi tumbuh maksimum, dan bobot kering berangkasan. Pemberian kombinasi konsentrasi boron dan $\mathrm{GA}_{3}(10+100)$ ppm mendominasi pada variabel pertumbuhan vegetatif kedelai.
\end{abstract}

Kata kunci: boron, GA kedelai

\section{PENDAHULUAN}

Kedelai (Glycine max [L.] Merril) adalah salah satu komoditas pangan penting setelah padi dan jagung yang juga merupakan sumber protein nabati. Kedelai memiliki banyak manfaat yang digunakan sebagai bahan makanan olahan seperti tempe, tahu, kecap, pakan ternak, dan bahan baku industri. Produksi kedelai di Indonesia masih rendah sedangkan kebutuhan kedelai terus meningkat seiring bertambahnya jumlah penduduk. Menurut data Badan Pusat Statistik (2016), produksi kedelai di Indonesia pada tahun 2015 mencapai 963.180 ton sedangkan kebutuhan kedelai mencapai 2,54 juta ton. Menurut Sudaryono, Taufik, dan Wijanako (2007), produksi kedelai rendah disebabkan oleh penggunaan benih bermutu rendah dan pemupukan yang kurang optimal sehingga perlu dilakukan upaya meningkatkan mutu benih kedelai.

Upaya peningkatan produksi kedelai dapat dilakukan dengan perbaikan teknik budidaya berupa pemupukan. Pemupukan dilakukan untuk memenuhi unsur hara karena keterbatasan unsur hara dalam tanah. Unsur hara terdiri atas unsur hara makro dan mikro. Unsur hara makro dibutuhkan dalam jumlah relatif banyak sedangkan unsur hara mikro relatif sedikit, pengelolaan unsur hara akan berpengaruh pada pertumbuhan tanaman kedelai. Salah satu unsur mikro yang dibutuhkan untuk pertumbuhan tanaman adalah boron.

Boron merupakan unsur mikro yang berperan penting pada tanaman. Boron merupakan mineral formalin yang mengalami pelapukan menjadi $\mathrm{BO}_{3}$. Tanaman menyerap boron dalam bentuk $\mathrm{H}_{3} \mathrm{BO}_{3}$. Boron berperan dalam pembelahan sel, respirasi, dan pertumbuhan tanaman. Kekurangan boron akan menyebabkan tanaman menjadi kerdil (Hanafiah, 2007). Pada tanaman kedelai boron berperan dalam proses transfer gula dan nutrisi, penyerbukan bunga, dan pembentukan biji. Kekurangan boron juga menyebabkan klorosis daun, daun mudah rapuh, fungsi akar terganggu, dan bunga layu sebelum berkembang (Tinto, 2012).

Perbaikan teknik budidaya juga dilakukan dengan pemberian zat pengatur tumbuh (ZPT). Penyemprotan ZPT berupa $\mathrm{GA}_{3}$ menyebabkan sel-sel pada tanaman bertambah jumlah dan ukurannya sehingga menyebabkan perpanjangan ruas tanaman. Menurut Salisbury dan Ross (1995), GA dapat menggantikan panjang hari yang dibutuhkan kedelai untuk proses 
pembungaan. Selain itu, tanggapan tanaman terhadap ZPT bergantung pada konsentrasi ZPT, bagian tanaman, fase perkembangan tanaman, interaksi antar-ZPT, dan faktor lingkungan. Konsentrasi yang tepat akan menentukan keefektifan $\mathrm{GA}_{3}$ dalam mendorong pertumbuhan tanaman. Azizi et al. (2012) menyimpulkan bahwa penyemprotan tanaman kedelai dengan konsentrasi $\mathrm{GA}_{3} 125 \mathrm{ppm}$ menghasilkan pertumbuhan, produksi, dan mutu benih tertinggi dibandingkan dengan konsentrasi 250 dan 375 ppm.

Siahaan (2015) menyatakan bahwa kombinasi boron dan $\mathrm{GA}_{3}$ mempunyai kurva linier positif terhadap jumlah bunga yang dihasilkan. Kurva linier positif juga ditunjukkan pada pengaruh kombinasi tersebut terhadap bobot biji yang dihasilkan. Boron mempengaruhi pembuahan dengan meningkatkan produksi serbuk sari di kepala sari dan viabilitas serbuk sari biji-bijian sehingga terjadi peningkatan persentase bunga menjadi polong. Peningkatan persentase bunga jadi polong akan meningkatkan jumlah biji. Giberelin memperbesar luas daun berbagai jenis tanaman, juga memperbesar ukuran bunga dan buah. Giberelin mendorong terbentuknya buah tanpa biji pada tanaman anggur dan beberapa jenih buah lainnya. Proses dormansi pada biji dan mata tunas juga dapat dihilangkan dengan penambahan giberelin. Dormansi biji yang diperpendek akan meningkatkan kecepatan perkecambahan benih.

Boron berperan dalam suplai nutrisi ke seluruh bagian tanaman yang akan meningkatkan metanolisme tanaman. Nutrisi yang disuplai oleh boron ke setiap bagian tanaman akan dimaksimalkan oleh $\mathrm{GA}_{3}$ untuk memperbesar ukuran dan jumlah sel. Boron yang merupakan unsur hara mikro dan giberelin yang merupakan hormon diperlukan tanaman dalam jumlah optimum. Kekurangan maupun kelebihan kedua unsur tersebut akan berdampak buruk bagi tanaman sehingga diperlukan kombinasi konsentrasi yang optimum untuk meningkatkan pertumbuhan, produksi, dan mutu benih kedelai. Kombinasi antara boron dan $\mathrm{GA}_{3}$ akan meningkatkan pertumbuhan, produksi, dan mutu benih kedelai. Percobaan ini dilakukan untuk menjawab masalah bagaimana pengaruh kombinasi konsentrasi boron dan $\mathrm{GA}_{3}$ terhadap pertumbuhan, produksi, dan mutu benih kedelai.

\section{BAHAN DAN METODE}

Penelitian ini dilaksanakan di Laboratorium Lapang Terpadu Fakultas Pertanian Universitas Lampung dari April sampai September 2015. Bahanbahan yang digunakan adalah kedelai varietas Wilis , tanah Ultisol, pupuk boron $\left(\mathrm{H}_{3} \mathrm{BO}_{3}\right)$, serbuk $\mathrm{GA}_{3}$, alkohol
$90 \%$, dan akuades. Alat-alat yang digunakan adalah cangkul, sekop, polibag ukuran $10 \mathrm{~kg}$, alat semprot, timbangan, alat pengukur panjang, gelas ukur, dan alat tulis.

Perlakuan disusun dalam rancangan perlakuan faktor tunggal tidak terstruktur yaitu kombinasi boron dan $\mathrm{GA}_{3}$. Perlakuan terdiri dari $0 \mathrm{ppm}$ boron dan $0 \mathrm{ppm}$ $\mathrm{GA}_{3}(0+0), 5 \mathrm{ppm}$ boron dan $20 \mathrm{ppm} \mathrm{GA}_{3}(5+20), 5$ ppm boron dan $40 \mathrm{ppm} \mathrm{GA}_{3}(5+40), 5$ ppm boron dan $60 \mathrm{ppm} \mathrm{GA} \mathrm{GA}_{3}(5+60), 5 \mathrm{ppm}$ boron dan $80 \mathrm{ppm} \mathrm{GA}_{3}(5$ $+80), 5$ ppm boron dan $100 \mathrm{ppm} \mathrm{GA}_{3}(5+100), 10 \mathrm{ppm}$ boron dan $20 \mathrm{ppm} \mathrm{GA}_{3}(10+20), 10 \mathrm{ppm}$ boron dan 40 ppm GA $3(10+40), 10$ ppm boron dan $60 \mathrm{ppm} \mathrm{GA}_{3}(10$ $+60), 10$ ppm boron dan 80 ppm GA $_{3}(10+80), 10 \mathrm{ppm}$ boron dan 100 ppm GA $3(10+100)$. Perlakuan diulang sebanyak delapan kali. Perbedaan antar kombinasi perlakuan diketahui dengan menggunakan standar deviasi.

Pengamatan terdiri dari tiga tahap, yaitu pengamatan pertumbuhan, produksi, dan mutu benih. Variabel pertumbuhan yang diamati terdiri dari: 1) Tinggi tanaman, dilakukan setiap minggu sampai tanaman berbunga. Tanaman diukur dari permukaan tanah sampai titik tumbuh batang utama. Pengukuran dilakukan dalam satuan sentimeter dengan menggunakan meteran. 2) Jumlah cabang, dilakukan pada saat tanaman telah memasuki fase generatif. Pengamatan dilakukan dengan dihitung dan dalam satuan buah. 3) Jumlah daun, dilakukan pada saat tanaman telah memasuki masa pengisian polong. Pengamatan dilakukan dengan dihitung dan dalam satuan helai. 4) Jumlah daun trifoliat, dilakukan pada saat tanaman telah memasuki masa pengisian polong. Pengamatan dilakukan dengan menghitung jumlah daun trifoliat dan dalam satuan helai. 5) Bobot kering berangkasan, terdiri dari tajuk tanaman dan dikeringkan dengan oven pada suhu $80^{\circ} \mathrm{C}$ selama dua hari sampai mencapai bobot kering konstan. Berangkasan kemudian ditimbang dengan timbangan elektrik dalam satuan gram.

Variabel produksi tanaman yang diamati terdiri dari: 1) Jumlah polong total, dilakukan dengan menghitung semua polong yang terbentuk pada tanaman kedelai. 2) Jumlah polong isi, dilakukan dengan menghitung jumlah polong isi dan dalam satuan buah. 3) Bobot polong isi, dilakukan pada saat panen dengan menimbang bobot polong isi dan dalam satuan gram. 4) Bobot biji, dilakukan dengan menimbang biji keseluruhan dan dalam satuan gram. 5) Bobot 100 butir, dilakukan pada saat panen dengan menimbang bobot 100 butir dari masing-masing kombinasi dan dalam satuan gram.

Variabel mutu benih yang diamati terdiri dari: 1) Persen perkecambahan, diperoleh dengan mengamati 
jumlah kecambah normal yang dihasilkan pada hari ke5 dan ke-7 dan dalam satuan persen (\%). 2) Kecepatan perkecambahan, diperoleh dengan pengamatan jumlah benih berkecambah pada hari ke-3 dan hari ke-5 dengan metode UKDdP (Uji Kertas Digulung dalam Plastik) sebanyak 25 butir tiap gulungan dan diulang sebanyak tiga kali dan dalam satuan persen (\%). 3) Bobot kering kecambah normal, diperoleh dengan menimbang kecambah normal yang telah dikeringkan selama $1 \times 24$ jam dengan suhu $121^{\circ} \mathrm{C}$ dan dalam satuan gram. 4) Potensi tumbuh maksimum, diperoleh dengan menghitung persen benih yang berkecambah pada hari ke 5 pengecambahan. Benih dikecambahkan dengan metode UKDdP (Uji Kertas Digulung dalam Plastik) sebanyak 25 butir tiap gulung dan diulang sebanyak tiga kali dan dalam satuan dengan persen (\%).

\section{HASIL DAN PEMBAHASAN}

Pengaruh kombinasi konsentrasi boron dan $\mathrm{GA}_{3}$ terhadap pertumbuhan vegetatif, generatif, dan mutu benih kedelai menunjukkan bahwa kombinasi konsentrasi $(10+60),(5+60)$, dan $(10+100)$ ppm cenderung meningkatkan nilai rata-rata pada variabel pertumbuhan, produksi, dan mutu benih kedelai cenderung lebih tinggi dibandingkan kombinasi lainnya. Pemberian $\mathrm{B}+\mathrm{GA}_{3}$ kombinasi konsentrasi $(10+60)$ ppm menunjukkan kecenderungan meningkatnya variabel pertumbuhan vegetatif, pertumbuhan generatif, dan mutu benih kedelai (Tabel 1, 2, dan 3) sedangkan kombinasi konsentrasi $(5+60)$ cenderung hanya meningkatkan variabel pertumbuhan vegetatif dan mutu benih kedelai (Tabel 1 dan 3). Pemberian $\mathrm{B}+\mathrm{GA}_{3}$ kombinasi konsentrasi $(10+100) \mathrm{ppm}$ cenderung lebih dominan dalam meningkatkan variabel pertumbuhan vegetatif yang juga cenderung meningkatkan pertumbuhan generatif dan mutu benih kedelai (Tabel 1, 2, dan 3).

Kombinasi konsentrasi B dan $\mathrm{GA}_{3}(10+60)$ ppm dapat meningkatkan mutu benih kedelai cenderung tinggi pada persen perkecambahan, kecepatan perkecambahan, dan potensi tumbuh maksimum. Tingginya potensi tumbuh maksimum dan persen perkecambahan menunjukkan bahwa benih daya hidup yang tinggi. Tingginya kecepatan perkecambahan menunjukkan bahwa vigor benih tinggi karena semakin cepat berkecambah maka semakin tinggi vigor kecambah (Arif et al., 2006). Vigor tinggi mencerminkan kondisi komposisi kimia cadangan makanan dalam benih cukup tinggi khususnya boron dan giberelin. Menurut Marschner (1995), boron memiliki peran dalam proses fisiologis tanaman seperti peningkatan pembelahan sel dan diferensiasi jaringan yang membantu proses perkecambahan. Peran $\mathrm{GA}_{3}$ dalam proses perkecambahan adalah dengan memperbesar dan menambah jumlah sel sehingga kecambah tumbuh dengan normal dan sehat (Wattimena, 1998). Pemberian kombinasi konsentrasi boron dan giberelin meningkatkan mutu benih tanaman kedelai dengan mempercepat diferensiasi jaringan dan pembelahan sel pada proses perkecambahan.

Mutu benih kedelai dipengaruhi oleh pertumbuhan dan produksinya. Kombinasi konsentrasi $(10+60) \mathrm{ppm}$ dapat meningkatkan pertumbuhan vegetatif tanaman kedelai cenderung tinggi pada tinggi tanaman, jumlah cabang, jumlah daun, dan jumlah daun trifoliat. Pemanjangan ruas batang (tinggi tanaman) terjadi karena pertambahan ukuran dan jumlah sel pada ruas-ruas batang tersebut (Wattimena, 1998). Pemanjangan batang memungkinkan terbentuknya jumlah cabang yang lebih banyak karena tersedia ruang tumbuh yang luas. Jumlah cabang yang lebih banyak dapat memberikan ruang tumbuh daun dan polong yang lebih tinggi. Tingginya jumlah daun terbentuk juga dipengaruhi oleh pemberian boron yang berperan dalam metabolisme, respirasi, dan pembelahan sel (Hanafiah,2007). Jumlah daun yang tinggi juga karena daun yang tidak mudah rapuh dan gugur sehingga dapat menahan jumlah daun lebih banyak pada waktu yang sama. Boron berfungsi mencegah klorosis daun, daun mudah rapuh, fungsi akar terganggu, dan bunga layu sebelum berkembang (Tinto, 2012). Jumlah daun yang tinggi memaksimalkan proses fotosintesis karena tingginya jumlah klorofil dan luas bidang daun. Tingginya fotosintat yang dihasilkan akan meningkatkan metabolisme tanaman kedelai sehingga mampu tumbuh dan berproduksi dengan baik. Pertumbuhan vegetatif tanaman dipengaruhi oleh boron sebagai aktifator maupun inaktifator hormon auksin dalam pembelahan dan pembesaran sel (Yudhie, 2008). Menurut Hamayun et al. (2010) hormon giberelin dapat mendorong pertumbuhan tanaman yang ditunjukkan dengan tingginya volume tajuk tanaman. Boron dan $\mathrm{GA}_{3}$ yang sama-sama memperbesar sel akan mempengaruhi volume tajuk yang tinggi ditunjukkan dengan tingginya variabel tinggi tanaman, jumlah cabang, jumlah daun, dan jumlah daun trifoliat.

Produksi tanaman kedelai yang diberi kombinasi konsentrasi $\mathrm{B}$ dan $\mathrm{GA}_{3}(10+60) \mathrm{ppm}$ dipengaruhi oleh pertumbuhan tanaman tersebut yang ditunjukkan dengan variabel-variabel pada fase produksi tanaman kedelai tersebut. Jumlah cabang yang tinggi menyebabkan ruang tumbuh bunga menjadi semakin luas sehingga meningkatkan jumlah bunga. Boron pada tanaman berfungsi untuk traslokasi gula ke membran, memengaruhi perkembangan sel-sel dalam pembentukan 
Tabel 1. Nilai rata-rata variabel vegetatif kedelai.

\begin{tabular}{|c|c|c|c|c|c|c|}
\hline \multirow{3}{*}{$\begin{array}{c}\text { Perlakuan } \\
\mathrm{B}+\mathrm{GA}_{3} \\
(\mathrm{ppm})\end{array}$} & \multicolumn{6}{|c|}{ Variabel } \\
\hline & \multicolumn{2}{|c|}{ Tinggi Tanaman } & \multicolumn{2}{|c|}{ Jumlah Cabang } & \multicolumn{2}{|c|}{ Jumlah Daun } \\
\hline & \multicolumn{2}{|c|}{$\overline{\mathrm{x}} \pm$ S. deviasi } & \multicolumn{2}{|c|}{$\overline{\mathrm{x}} \pm$ S. deviasi } & \multicolumn{2}{|c|}{$\overline{\mathrm{x}} \pm$ S. deviasi } \\
\hline $0+0$ & $73,86 \pm 1,55$ & $72,31-75,41$ & $2,60 \pm 0,24$ & $2,36-2,84$ & $63,14 \pm 1,37$ & $61,77-64,51$ \\
\hline $5+20$ & $95,50 \pm 1,88$ & $93,62-97,38$ & $4,43 \pm 0,20$ & $4,23-4,63$ & $69,71 \pm 1,41$ & $68,30-71,12$ \\
\hline $5+40$ & $106,75 \pm 2,14$ & $104,61-108,89$ & $4,50 \pm 0,50$ & $4,00-5,00$ & $82,67 \pm 1,99$ & $80,67-84,66$ \\
\hline $5+60$ & $105,00 \pm 2,21$ & $102,79-107,21$ & $3,86 \pm 0,14$ & $3,71-4,00$ & $72,71 \pm 1,78$ & $70,93-74,50$ \\
\hline $5+80$ & $105,14 \pm 3,08$ & $102,06-108,22$ & $3,86 \pm 0,40$ & $3,45-4,26$ & $81,83 \pm 1,74$ & $80,09-83,57$ \\
\hline $5+100$ & $116,50 \pm 1,72$ & $114,78-118,22$ & $4,00 \pm 0,38$ & $3,62-4,38$ & $78,50 \pm 2,16$ & $76,34-80,66$ \\
\hline $10+20$ & $121,25 \pm 1,87$ & $119,38-123,12$ & $4,75 \pm 0,25$ & $4,50-5,00$ & $90,00 \pm 1,88$ & $88,12-91,88$ \\
\hline $10+40$ & $125,88 \pm 1,66$ & $124,21-127,54$ & $4,43 \pm 0,20$ & $4,23-4,63$ & $99,00 \pm 1,65$ & $97,35-100,65$ \\
\hline $10+60$ & $126,75 \pm 1,70$ & $125,05-128,45$ & $5,40 \pm 0,24$ & $5,16-5,64$ & $97,86 \pm 2,02$ & $95,84-99,87$ \\
\hline $10+80$ & $128,00 \pm 2,25$ & $125,75-130,25$ & $4,71 \pm 0,18$ & $4,53-4,90$ & $97,33 \pm 1,78$ & $95,55-99,12$ \\
\hline $10+100$ & $131,86 \pm 2,72$ & $129,14-134,58$ & $5,63 \pm 0,18$ & $5,44-5,81$ & $95,88 \pm 2,32$ & $93,56-98,19$ \\
\hline \multirow{3}{*}{$\begin{array}{c}\text { Perlakuan } \\
\mathrm{B}+\mathrm{GA}_{3} \\
(\mathrm{ppm})\end{array}$} & \multicolumn{6}{|c|}{ Variabel } \\
\hline & \multicolumn{3}{|c|}{ Jumlah Daun Trifoliat } & \multicolumn{3}{|c|}{ Bobot Kering Berangkasan } \\
\hline & \multicolumn{3}{|c|}{$\overline{\mathrm{x}} \pm$ S. deviasi } & \multicolumn{3}{|c|}{$\overline{\mathrm{x}} \pm$ S. deviasi } \\
\hline $0+0$ & $19,24 \pm 0,79$ & 18,45 &, 03 & $14,17 \pm$ & & $92-15,42$ \\
\hline $5+20$ & $23,24 \pm 0,47$ & 22,77 & 3,71 & $15,64 \pm$ & & $41-16,88$ \\
\hline $5+40$ & $27,56 \pm 0,66$ & 26,89 & 8,22 & $18,96 \pm$ & & $78-20,13$ \\
\hline $5+60$ & $23,67 \pm 0,85$ & $22,82-$ & 4,52 & $24,97 \pm$ & & $64-26,31$ \\
\hline $5+80$ & $27,28 \pm 0,58$ & 26,70 & 7,86 & $24,30 \pm$ & & $96-25,64$ \\
\hline $5+100$ & $26,04 \pm 1,07$ & 24,97 & 7,11 & $26,07 \pm$ & & $90-27,24$ \\
\hline $10+20$ & $29,29 \pm 1,08$ & 28,22 & 0,37 & $17,29 \pm$ & & $14-18,43$ \\
\hline $10+40$ & $30,95 \pm 1,04$ & $29,91-$ & 1,99 & $19,80 \pm$ & & $61-20,99$ \\
\hline $10+60$ & $31,38 \pm 1,05$ & 30,33 & 2,43 & $21,49 \pm$ & & $15-22,82$ \\
\hline $10+80$ & $31,39 \pm 1,04$ & 30,34 & 2,43 & $22,51 \pm$ & & $30-23,72$ \\
\hline $10+100$ & $31,17 \pm 1,03$ & 30,14 & 2,20 & $24,33 \pm$ & & $02-25,63$ \\
\hline
\end{tabular}

polisakarida, dan kecepatan pembelahan sel (Hanafiah, 2007). Selain itu giberelin yang diberikan dapat memenuhi kebutuhan beberapa jenis tanaman akan masa dingin untuk menginduksi pembungaan atau agar pembungaan terjadi lebih awal (Salisbury dan Ross, 1995). Jumlah bunga yang tinggi dan tidak layu dapat meningkatkan jumlah polong total yang memungkinkan meningkatnya jumlah polong isi. Pada tanaman kedelai boron berperan dalam proses transfer gula dan nutrisi, penyerbukan bunga, dan pembentukan biji (Tinto, 2012). Pembungaan yang lebih awal memengaruhi waktu pengisian polong. Fotosintat (gula) yang ditranslokasikan oleh boron pada benih yang berukuran lebih besar karena pengaruh $\mathrm{GA}_{3}$ memengaruhi mutu benih yang berhubungan dengan cadangan makanan dalam benih. Bobot polong isi dan bobot biji yang terbentuk pada 
Tabel 2. Nilai rata-rata variabel generatif kedelai.

\begin{tabular}{|c|c|c|c|c|c|c|c|}
\hline \multirow{3}{*}{$\begin{array}{c}\text { Perlakuan } \\
\mathrm{B}+\mathrm{GA}_{3} \\
(\mathrm{ppm})\end{array}$} & \multicolumn{7}{|c|}{ Variabel } \\
\hline & \multicolumn{3}{|c|}{ Jumlah Polong Total } & \multicolumn{2}{|c|}{ Jumlah Polong Isi } & \multicolumn{2}{|c|}{ Bobot Polong Isi } \\
\hline & \multicolumn{3}{|c|}{$\overline{\mathrm{x}} \pm$ S. deviasi } & \multicolumn{2}{|c|}{$\overline{\mathrm{x}} \pm$ S. deviasi } & \multicolumn{2}{|c|}{$\overline{\mathrm{x}} \pm$ S. deviasi } \\
\hline $0+0$ & $62,13 \pm 1,30$ & \multicolumn{2}{|c|}{$60,82-63,43$} & $54,96 \pm 1,32$ & $53,64-56,27$ & $25,40 \pm 1,28$ & $24,12-26,68$ \\
\hline $5+20$ & $69,88 \pm 0,81$ & \multicolumn{2}{|c|}{$69,06-70,69$} & $65,81 \pm 1,14$ & $64,67-66,94$ & $28,24 \pm 0,91$ & $27,33-29,15$ \\
\hline $5+40$ & $73,63 \pm 0,84$ & \multicolumn{2}{|c|}{$72,78-74,47$} & $65,95 \pm 1,10$ & $64,85-67,05$ & $28,48 \pm 0,61$ & $27,86-29,09$ \\
\hline $5+60$ & $73,25 \pm 1,36$ & \multicolumn{2}{|c|}{$71,89-74,61$} & $65,81 \pm 1,36$ & $64,44-67,17$ & $29,41 \pm 0,71$ & $28,70-30,13$ \\
\hline $5+80$ & $75,38 \pm 1,07$ & \multicolumn{2}{|c|}{$74,31-76,44$} & $72,02 \pm 1,10$ & $70,92-73,12$ & $33,30 \pm 1,43$ & $31,87-34,73$ \\
\hline $5+100$ & $70,25 \pm 1,60$ & \multicolumn{2}{|c|}{$68,65-71,85$} & $70,35 \pm 1,01$ & $69,33-71,36$ & $31,97 \pm 1,35$ & $30,62-33,32$ \\
\hline $10+20$ & $80,13 \pm 1,29$ & \multicolumn{2}{|c|}{$78,84-81,41$} & $72,43 \pm 1,09$ & $71,33-73,52$ & $33,54 \pm 1,13$ & $32,41-34,67$ \\
\hline $10+40$ & $79,38 \pm 1,08$ & \multicolumn{2}{|c|}{$78,29-80,46$} & $71,22 \pm 1,75$ & $69,46-72,97$ & $35,89 \pm 2,30$ & $33,58-38,19$ \\
\hline $10+60$ & $82,50 \pm 0,82$ & \multicolumn{2}{|c|}{$81,68-83,32$} & $79,20 \pm 1,01$ & $78,18-80,21$ & $34,98 \pm 1,60$ & $33,38-36,59$ \\
\hline $10+80$ & $82,38 \pm 0,92$ & \multicolumn{2}{|c|}{$81,45-83,30$} & $76,68 \pm 1,17$ & $75,51-77,85$ & $34,80 \pm 1,42$ & $33,38-36,22$ \\
\hline $10+100$ & $85,63 \pm 0,82$ & \multicolumn{2}{|c|}{$84,80-86,45$} & $75,76 \pm 1,34$ & $74,42-77,10$ & $33,60 \pm 0,87$ & $32,73-34,47$ \\
\hline Perlakuan & \multicolumn{7}{|c|}{ Variabel } \\
\hline $\mathrm{B}+\mathrm{GA}_{3}$ & & & & & & Bobot 100 But & \\
\hline (ppm) & & $\overline{\mathrm{x}} \pm$ & tiasi & & & $\overline{\mathrm{x}} \pm$ S. devias & \\
\hline $0+0$ & $17,73 \pm 1$ & & & $8-18,89$ & $17,73 \pm$ & 1,15 & $6,58-18,89$ \\
\hline $5+20$ & $22,32 \pm 1$ & & & $0-23,64$ & $22,32 \pm$ & 1,32 & $1,00-23,64$ \\
\hline $5+40$ & $19,64 \pm 0$ & & & $0-20,18$ & $19,64 \pm$ & 0,54 & $9,10-20,18$ \\
\hline $5+60$ & $24,58 \pm 0$ & & & $1-25,35$ & $24,58 \pm$ & 0,77 & $3,81-25,35$ \\
\hline $5+80$ & $24,97 \pm 2$ & & & $6-27,67$ & $24,97 \pm$ & 71 & $2,26-27,67$ \\
\hline $5+100$ & $27,30 \pm 1$ & & & $9-28,62$ & $27,30 \pm$ & 1,32 & $5,99-28,62$ \\
\hline $10+20$ & $26,21 \pm 0$ & & & $2-27,20$ & $26,21 \pm$ & 0,99 & $5,22-27,20$ \\
\hline $10+40$ & $32,17 \pm 2$ & & & $1-34,63$ & $32,17 \pm$ & 2,46 & $9,71-34,63$ \\
\hline $10+60$ & $31,32 \pm 1$ & & & $0-32,94$ & $31,32 \pm$ & 1,62 & $9,70-32,94$ \\
\hline $10+80$ & $31,88 \pm 1$ & & & $1-33,46$ & $31,88 \pm$ & 1,58 & $0,31-33,46$ \\
\hline $10+100$ & $30,82 \pm 0$ & & & $0-31,65$ & $30,82 \pm$ & 0,82 & $0,00-31,65$ \\
\hline
\end{tabular}

kombinasi konsentrasi $(10+60)$ ppm yang cenderung tinggi juga dipengaruhi oleh tingginya jumlah daun sehingga mampu menghasilkan fotosintat yang cukup untuk fase pengisian polong.

Pemberian B dan $\mathrm{GA}_{3}(5+60)$ ppm lebih cenderung meningkatkan pertumbuhan vegetatif dan mutu benih, tetapi cenderung tidak mempengaruhi pertumbuhan generatif. Kombinasi konsentrasi $(5+60)$ ppm dapat meningkatkan mutu benih tanaman kedelai cenderung tinggi pada persen perkecambahan, bobot kering kecambah normal dan potensi tumbuh maksimum. Bobot kering kecambah normal yang tinggi menunjukan tingginya cadangan makanan yang ada dalam benih. Cadangan makanan yang tinggi menunjukkan bahwa fotosintat tanaman tersebut dalam jumlah tinggi. Candangan makanan yang tinggi dapat menumbuhkan kecambah normal dengan keadaan sehat dengan potensi perkecambahan yang tinggi. 
Tabel 3. Nilai rata-rata variabel mutu benih kedelai.

\begin{tabular}{ccccc}
\hline \multirow{2}{*}{$\begin{array}{c}\text { Perlakuan B }+\mathrm{GA}_{3} \\
(\mathrm{ppm})\end{array}$} & \multicolumn{3}{c}{ Persen perkecambahan } & \multicolumn{2}{c}{ Kecepatan Perkecambahan } \\
\cline { 2 - 5 } & \multicolumn{3}{c}{$\overline{\mathrm{x}} \pm$ S. deviasi } & \multicolumn{2}{c}{$\overline{\mathrm{x}} \pm$ S. deviasi } \\
\cline { 2 - 5 } & $81,00 \pm 1,91$ & $79,09-82,91$ & $26,92 \pm 1,04$ & $25,88-27,96$ \\
$5+0$ & $91,00 \pm 1,91$ & $89,09-92,91$ & $27,00 \pm 0,68$ & $26,32-27,68$ \\
$5+40$ & $90,00 \pm 2,00$ & $88,00-92,00$ & $29,83 \pm 0,70$ & $29,13-30,53$ \\
$5+60$ & $92,00 \pm 4,32$ & $87,68-96,32$ & $33,83 \pm 1,43$ & $32,40-35,26$ \\
$5+80$ & $90,00 \pm 2,58$ & $87,42-92,58$ & $32,08 \pm 1,57$ & $30,51-33,65$ \\
$5+100$ & $92,00 \pm 2,83$ & $89,17-94,83$ & $34,00 \pm 1,67$ & $32,33-35,67$ \\
$10+20$ & $94,00 \pm 2,58$ & $91,42-96,58$ & $40,83 \pm 1,44$ & $39,39-42,28$ \\
$10+40$ & $92,00 \pm 4,32$ & $87,68-96,32$ & $38,08 \pm 1,33$ & $36,75-39,41$ \\
$10+60$ & $95,00 \pm 3,00$ & $92,00-98,00$ & $40,50 \pm 0,91$ & $39,59-41,41$ \\
$10+80$ & $93,00 \pm 1,91$ & $91,09-94,91$ & $35,83 \pm 1,02$ & $34,81-36,86$ \\
$10+100$ & $92,00 \pm 2,83$ & $89,17-94,83$ & $37,33 \pm 1,34$ & $35,99-38,67$ \\
\hline
\end{tabular}

\begin{tabular}{ccccc}
\hline \multirow{2}{*}{$\begin{array}{c}\text { Perlakuan B + GA } 3 \\
\text { (ppm) }\end{array}$} & \multicolumn{4}{c}{ Variabel } \\
\cline { 2 - 5 } & \multicolumn{3}{c}{$\bar{c}$ Bobot Kering Kecambah Normal } & \multicolumn{2}{c}{ Potensi Tumbuh Maksimum } \\
\cline { 2 - 5 } & $0,0367 \pm 0,0011$ & $0,0357-0,0378$ & $87,00 \pm 2,52$ & $84,48-89,52$ \\
$5+0$ & $0,0338 \pm 0,0009$ & $0,0329-0,0347$ & $97,00 \pm 1,91$ & $95,09-98,91$ \\
$5+40$ & $0,0375 \pm 0,0019$ & $0,0357-0,0394$ & $96,00 \pm 1,63$ & $94,37-97,63$ \\
$5+60$ & $0,0404 \pm 0,0011$ & $0,0393-0,0415$ & $98,00 \pm 2,00$ & $96,00-100,00$ \\
$5+80$ & $0,0365 \pm 0,0014$ & $0,0352-0,0379$ & $94,00 \pm 2,58$ & $91,42-96,58$ \\
$5+100$ & $0,0382 \pm 0,0012$ & $0,0371-0,0394$ & $96,00 \pm 1,63$ & $94,37-97,63$ \\
$10+20$ & $0,0361 \pm 0,0017$ & $0,0344-0,0377$ & $99,00 \pm 1,00$ & $98,00-100,00$ \\
$10+40$ & $0,0338 \pm 0,0009$ & $0,0329-0,0347$ & $98,00 \pm 2,00$ & $96,00-100,00$ \\
$10+60$ & $0,0365 \pm 0,0021$ & $0,0343-0,0386$ & $98,00 \pm 1,15$ & $96,85-99,15$ \\
$10+80$ & $0,0357 \pm 0,0020$ & $0,0337-0,0376$ & $97,00 \pm 1,00$ & $96,00-98,00$ \\
$10+100$ & $0,0375 \pm 0,0013$ & $0,0362-0,0388$ & $97,00 \pm 1,91$ & $95,09-98,91$ \\
\hline
\end{tabular}

Mutu benih tanaman kedelai dipengaruhi oleh pertumbuhan dan produksinya. Kombinasi konsentrasi $(5+60)$ ppm dapat meningkatkan pertumbuhan tanaman kedelai cenderung tinggi pada bobot kering berangkasan. Selisih konsentrasi boron sebanyak 5 ppm jika dibandingkan dengan kombinasi konsentrasi $(10+60)$ tidak menunjukkan tingginya jumlah cabang, jumlah daun, dan jumlah daun trifoliat. Kombinasi konsentrasi $\mathrm{B}$ dan $\mathrm{GA}_{3}(5+60)$ ppm memiliki bobot kering berangkasan tinggi yang menunjukkan bahwa tanaman mengalami proses metabolisme yang baik. Hasil tersebut diduga karena peran kombinasi $\mathrm{B}$ dan $\mathrm{GA}_{3}$ berperan dalam proses transfer gula dan nutrisi. Pertumbuhan vegetatif yang baik pada kombinasi konsentrasi $(5+60)$ ppm tidak menunjang peningkatan pertumbuhan generatif tanaman kedelai yang ditunjukkan dengan tidak adanya variabel yang cenderung tinggi bila dibandingkan dengan kombinasi konsentrasi lainnya. 
Konsentrasi $(10+100)$ ppm mendominasi pada variabel pertumbuhan kedelai. Kombinasi konsentrasi $(10+100)$ ppm dapat meningkatkan mutu benih kedelai cenderung tinggi pada persen perkecambahan dan potensi tumbuh maksimum. Mutu benih kedelai dipengaruhi oleh pertumbuhan dan produksinya. Berdasarkan hasil penelitian, kombinasi B dan $\mathrm{GA}_{3}(10$ $+100)$ ppm cenderung lebih dominan meningkatkan nilai rata-rata variabel vegetatif tanaman kedelai. Kombinasi konsentrasi B dan $\mathrm{GA}_{3}(10+100)$ lebih tinggi daripada kombinasi konsentrasi $(5+50)$ dan $(10+60)$ ppm. Konsentrasi B dan $\mathrm{GA}_{3}$ mempengaruhi jumlah dan ukuran sel serta transfer fotosintat ke seluruh bagian tubuh tanaman sehingga pertumbuhan vegetatif lebih dominan daripada pertumbuhan generatif. Pertumbuhan vegetatif ditunjukkan melalui tinggi tanaman, jumlah cabang, jumlah daun, jumlah daun trifoliat, dan bobot kering berangkasan dikarenakan konsentrasi $\mathrm{GA}_{3}$ yang tinggi (100 ppm) mengakibatkan meningkatnya jumlah dan ukuran sel sehingga menyebabkan volume tajuk tanaman tinggi

Produksi tanaman kedelai dipengaruhi oleh pertumbuhan tanaman tersebut. Kombinasi $\mathrm{B}$ dan $\mathrm{GA}_{3}$ $(10+100)$ ppm memiliki kecenderungan meningkatkan produksi tanaman kedelai. Kombinasi konsentrasi $(10+100) \mathrm{ppm}$ dapat meningkatkan produksi tanaman kedelai cenderung tinggi pada jumlah polong total, bobot polong isi, dan bobot biji. Variabel pertumbuhan generatif yang tinggi disebabkan oleh volume tajuk tanaman yang besar sehingga mampu menghasilkan ruang tumbuh polong dan fotosintat yang cukup untuk fase pembentukan dan pengisian polong.

\section{KESIMPULAN}

Pemberian kombinasi konsentrasi boron dan $\mathrm{GA}_{3}$ $(10+60)$ ppm menghasilkan pertumbuhan, produksi, dan mutu benih kedelai cenderung tinggi dibandingkan dengan kombinasi konsentrasi lainnya. Kombinasi konsentrasi boron dan $\mathrm{GA}_{3}$ dengan konsentrasi boron yang lebih rendah $(5+60)$ ppm cenderung tinggi hanya pada pertumbuhan dan mutuh benih daripada kombinasi konsentrasi lainnya.

\section{DAFTAR PUSTAKA}

Arif, M., M.A. Khan, H. Akbar, Sajjad, dan S. Ali. 2006. Prospect of Wheat as a Dual Purpose Crop and Its Impact on Weeds. Pak. J. Weed Sci. Res. 12: 13-17.
Azizi Kh., J. Moradii, S. Heidari, A. Khalili, dan M. Feizan. 2012. Effect of Different Concentrations of Gibberelic Acid on Seed Yield and Yield Components of Soy Bean Genotypes in Summer Intercropping. International Journal of Agriscience. 2(4): 291-301.

Badan Pusat Statistik. 2016. Produksi Padi, Jagung, dan Kedelai. Produksi Padi Tahun 2015 Naik 6,42 Persen. https://bps.go.id/index.php/brs/1272. Diakses pada tanggal 30 April 2017.

Hanafiah, A. K. 2007. Dasar-dasar Ilmu Tanah. PT Raja Grafindo Persada. Jakarta.

Hemayun, M., E. Shon, S.A. Khan, Z.K. Shinwari, A.L. Khan, dan I. Lee. 2010. Silicon Alleviates the Adverse Effects of Salinity and Drought Stress on Growth and Endogenous Plant Growth Hormone of Soybean (Glycine max L.). Pak. J. Bot. 42(3): 1.713-1.722.

Marschner, H. 1995. Mineral Nutrition of Higher Plant. Second Edition. Academic Press. Harcourt Brace \& Company, Publisher. London. 889 hlm.

Salisbury, F. D. dan C. W. Ross. 1995. Fisiologi Tumbuhan III. Diterjemahkan oleh Lukman, D. R. dan Sumaryono dari buku Plant Physiology. Penerbit ITB. Bandung.

Siahaan, F. Y. 2015. Produksi Bunga dan Biji Bawang Merah Lokal Samosir (Allium ascalonicum) pada Beberapa Konsentrasi GA3 dan Dosis Boron. Skripsi. Fakultas Pertanian Universitas Sumatera Utara. Medan. Vol.3(3): 3-4.

Sudaryono, A. Taufik, dan A. Wijanarko. 2007. Peluang Peningkatan Produksi Kedelai di Indonesia. In: Kedelai Teknik Produksi dan Pengembangan, disunting oleh Sumarno, Suyamto, Adi Widjono, Hermanto, dan Kusni Kasim. Badan Penelitian dan Pengembangan Pertanian. Bogor. $521 \mathrm{hlm}$.

Tinto, R. 2012. Boron applications for increased soy bean yield. Availabel online at: http:// www.riotintominerals.com, [10 April 2016].

Wattimena, G.A. 1988. Zat Pengatur Tumbuh Tanaman. Pusat Antar-Universitas, Institut Pertanian Bogor Bekerja Sama dengan Lembaga Sumbar Daya Informasi-IPB. Bogor. $145 \mathrm{hlm}$.

Yudhie. 2008. Pengaruh Unsur Esensial terhadap Pertumbuhan dan Produksi Tanaman. Available online at: http://www.tanindo.com/abdi4/ hal2701.htm, [14 Februari 2016]. 